\title{
Social Aid of Covid-19 Corruption: Strategy and Mitigation Policy of Muhammadiyah East Java
}

\author{
Satria Unggul Wicaksana Prakasa ${ }^{1 *}$, Achmad Hariri $^{2}$, Ida Nuriyah ${ }^{3}$, Asis $^{4}$, \\ Idrus Salam,
}

1,2,3,4,5 Faculty of Law, University of Muhammadiyah Surabaya, Surabaya, East Java, 60123, Indonesia.

*Corresponding author email address: satria@fh.um-surabaya.ac.id

\begin{tabular}{|c|c|}
\hline Article & Abstract \\
\hline $\begin{array}{l}\text { Article History } \\
\text { Received: January 7, 2021; } \\
\text { Reviewed: January 11, 2021; } \\
\text { Accepted: January 28, } \\
\text { 2021; } \\
\text { Published: February 2, } 2021\end{array}$ & $\begin{array}{l}\text { This research underlines several problems related to the potential for } \\
\text { corruption in social assistance (Bansos) provided by the Government } \\
\text { through the allocation of the State Budget (APBN) and/or Regional } \\
\text { Budget (APBD) to mitigate the economic impact and welfare of the } \\
\text { community amid the Covid-19 pandemic. This research was intended } \\
\text { to understand the role of Muhammadiyah as a civil society entity for } \\
\text { the pattern of guarding the distribution of social assistance throughout } \\
\text { East Java Province. The research approach used Participatory Action } \\
\text { Research (PAR) and used socio-legal approach, which is an approach } \\
\text { to control corruption based on community solidarity. The data } \\
\text { collection was interviewed, FGD, and dissemination conducted } \\
\text { online. Conclusions for this research are: (1). Corruption of the } \\
\text { Covid-19 Social Assistance Agency is a serious threat and is } \\
\text { detrimental to the Indonesian people who were severely affected by } \\
\text { the pandemic, even though the Corruption Act has provided a serious } \\
\text { threat to perpetrators of corruption committed during a disaster, with } \\
\text { a maximum penalty of death; (2). The KPK-RI as the lead sector for } \\
\text { corruption eradication in Indonesia can collaborate with various } \\
\text { community groups on the agenda of eradicating corruption in } \\
\text { Indonesia, especially the corruption of Covid-19 social Aid, through } \\
\text { access to community-based reporting, and; (3). Participatory Action } \\
\text { Research carried out by Muhammadiyah East Java residents is an } \\
\text { effective step and a good example of how social entities are able to } \\
\text { mitigate the potential for social assistance corruption of Covid-19 } \\
\text { which is carried out both with a structural to cultural approach. }\end{array}$ \\
\hline
\end{tabular}

(C)2021; This is an Open Acces Research distributed under the term of the Creative Commons Attribution Licencee (https://Creativecommons.org/licences/by/4.0), which permits unrestricted use, distribution, and reproduction in any medium, provided the original works is properly cited. 


\section{INTRODUCTION}

Nowadays, corruption in Indonesia involves the government and the legislature (especially the DPR-RI) as political elites who directly or indirectly commit acts of corruption. They do both in the aspects of procurement of goods and services, bribery, gratuities. Including in the bureaucratic and licensing sectors, the business climate in Indonesia is closely related to the practice of bribery and extortion. This is exacerbated by corruption in the judicial sector which causes the institution difficult to produce a fair and impartial court (Transparency International, 2018).

At least, there are several risk areas to corruption practices. Those have a high risk of corrupt practices where the Indonesian people interact directly and have the potential to guard against these corruption practices. Those sectors are: corruption in the procurement of goods and services, bribery and gratification, bribery in the licensing sector, bribery in the aspect of General Elections, corruption in the judicial sector, to corruption in village funds. Therefore, in this legal research, it tries to find a pattern of movement of appropriate social control such as whether in efforts to prevent and eradicate corruption in Indonesia. So that the aspirations of the state in realizing public welfare and fulfilling people's needs can be completely fulfilled (Prakasa, 2020b).

The Corruption Perception Index (CPI) of Indonesia in 2019 released by Transparency International said Indonesia's score at 40 points, and Indonesia was ranked 85 out of 180 countries worldwide (Haris \& Al-Fatih, 2020). Indonesia's GPA scores are the same as other developing countries such as Burkina Faso, Guyana, Lesotho, and Trinidad \& Tobago. Meanwhile in ASEAN, Indonesia's GPA is in 4th place and lower than Singapore (4th place, score 85), Brunei Darussalam (35th, 60th), and Malaysia (51st, 53) (Transparency International, 2019). The score was based on corrupt practices which are still attached to both government power, law enforcement, and the permissiveness of the Indonesian people to corrupt practices. ICW's study regarding the trend of corruption prosecution in 2018 reminded the public that corruption in the procurement of goods and services was the highest with 214 cases of corruption and state losses of Rp. 937 billion.

The Corruption Case for Social Assistance Covid-19 became one of the cases that caught the attention of the public at the end of 2020. The one who committed corruption was the Indonesian Minister of Social Affairs, Julari P. Batubara in procuring social assistance for handling covid-19 in the form of basic food packages at the Indonesian Ministry of Social Affairs 2020. The procurement was worth around IDR5.9 trillion, with a total of 272 contracts and is carried out in two periods. Juliari appointed Matheus Joko Santoso and Adi Wahyono as Commitment Making Officers $(\mathrm{PPK})$ in the implementation of the project by direct appointment of partners. From this effort, it is suspected that it was agreed that there was a fee for each work package that the partners had to deposit to the Ministry of Social Affairs through Matheus. The 
fee for each social assistance package was agreed upon by Matheus and Adi of IDR 10,000 per food package, of a value of IDR 300 thousand per-Bansos package (Indonesia, 2020).

The Commission of Eradication Corruption of Republic of Indonesia (Komisi Pemberantasan Korupsi Republik Indonesia-KPK-RI) stated that there were four risk areas for the occurrence of corrupt practices during the Covid-19 pandemic, namely: (1). Corruption in the procurement of goods and services, one of which is related to personal protective equipment (PPE), drugs, vaccines, etc .; (2). Refocusing and reallocation of the Covid-19 budget in the APBN and APBD which provide impunity for the government not to be prosecuted legally and without accountability, based on Law Number 2 of 2020; (3). Managing philanthropy or third party donations which are categorized as non-gratuities; (4). Organizing social assistance that is not right on target and manipulative (Prasetyo, 2020).

Furthermore, the Indonesian Ombudsman study deals with 5 (five) potential maladministration and potential corruption during the Covid-19 pandemic, namely: (1) Social Assistance, (2) Health, (3) Transportation, (4) Security, (5) Finance. Reports related to suspected maladministration have been reported to the RI Ombudsman and most of these reports have been resolved. In the top 5 (five) classifications, the highest reports submitted by the public include; (1) distribution of aid that is not evenly distributed in terms of time and people in the target area, (2) people who are in a more emergency condition are hungry, are not registered and vice versa, (3) are registered but do not receive assistance, (4) the means of complaints are less socialized to providers assistance, (5) unable to receive assistance at the place of residence, because of the immigrant Identity Card (KTP) (Ombudsman RI, 2020).

The Covid-19 social assistance corruption case was a very surprising phenomenon and strengthens the allegations that have so far been built. How it affect the misery of society during difficult times due to the Covid-19 pandemic, Article 2 paragraph (2) of Law Number 31 of 1999. It explains which carried out by state officials as well as individuals and corporations who under certain circumstances in Covid-19 pandemic case committing corruption can be sentenced to death as the maximum criminal sanction, corrupt political relations, low political morale, and nonaccountability become disastrous in the case corruption in Indonesia (Haliim, 2020).

Anti-corruption awareness must be an integral part of efforts to eradicate Covid19. The involvement of KPK as the leading sector in eradicating corruption as well as civil society entities that have a concern in the anti-corruption sector is very important in guarding the enforcement of the Covid-19 Pandemic so that no individuals and cartels engage in corrupt practices amid the sorrow experienced by the Indonesian people (Prakasa, 2020a).

One of the largest civil society entities in Indonesia is Muhammadiyah. Through the Muhammadiyah Central Leadership, he declared that the outbreak was an 
extraordinary event that must be immediately taken to prevent and take serious, massive and well-coordinated action. Muhammadiyah encouraged the government to involve all parties to work together and synergize, accompanied by open and comprehensive socialization and policy steps. Based on Muhammadiyah Central Leadership Declaration Number 02/Mlm/I.0/H/2020 About Coronavirus Disease 2019 (Covid-19), the Muhammadiyah Central Executive has formed the Muhammadiyah Covid-19 Command Center (MCCC) which is in charge of coordinating program implementation and actions. handling Covid-19, starting from the preventive, curative aspects, to mobilizing the potential of a participatory-based Muhammadiyah organization in handling Covid-19 (MCCC, 2020a).

The potential for social assistance corruption in handling Covid-19 can run transparency and accountability if civil society entities then oversee the distribution of the social assistance channeled through the government. Moreover, East Java Province and Surabaya City are in the category of areas most affected by Covid-19 (Hastuti, 2020) Of course this has an impact on the increasing number of social assistance distributions to East Java Province, while at the same time the potential for corruption is higher. Therefore, the role of Muhammadiyah East Java, especially the East Java Province MCCC, which has a structural base starting from the Subdistrict/Village, Branch/District, and Regional/Regency/City levels is expected to be able to anticipate the occurrence of Bansos corruption. This research is contribute for legal framework for eradication of social aid of Covid-19 corruption in Indonesia

Based on the above problems, the problem formulations taken in the following research are:

1. How is the implementation of social assistance for Covid-19 and the potential, opportunities, obstacles and challenges in mitigating the risk of corruption in social assistance for Covid-19?

2. How is the effectiveness of Participatory Action Research (PAR) in finding various models of corrupt practices, and their relation to the potential for social assistance corruption of Covid-19, especially in terms of the experience of Muhamamdiyah in East Java?

\section{METHOD}

Participatory action research (PAR) is a participatory research method among community members in a community, both elite and marginalized groups with a spirit to encourage transformative actions to liberate society from the shackles of power (including the mechanism for mitigating corrupt practices). Thus, according to the term PAR has three main pillars, namely research methodology, dimensions of action and dimensions of participation. This means that PAR is carried out with reference to certain research methodologies, must aim to encourage transformative action, and 
must involve as many citizens as possible or community members as implementers of PAR itself (LBH Jakarta, 2013).

In PAR activities, researchers / practitioners PAR immersed themselves in the reality of the community being studied, and work with residents in conducting PAR. PAR disscussed the condition of society based on the meaning system that applies there. It was not according to certain disciplines outside the culture of the community (Kemmis et al., 2014). PAR can no longer take a "value-free" and impartial position as demanded by science as a condition of objectivity, but must side with the weak, poor, disadvantaged, and victims of corrupt practices, in this case the people affected by Covid-19.

In addition, PAR did not stop at the publication of research results (reports) and recommendations for future research, but was oriented towards changing situations, increasing knowledge and the ability of citizens to understand and change their situation for the better. So, PAR method was very appropriate to be used in research that closely related to finding patterns of corrupt practices around society. Then it will be followed up in real patterns of advocacy and action (Zuber-Skerritt, 2016).

The data collected by means of interviews, observations, FGD and online documentation. The analysis technique used data triangulation. So, it is hoped that a pattern of monitoring and even reporting of community-based social assistance corruption will be obtained. This research conducted by taking place at the MCCC regional leadership of Muhammadiyah East Java, as well as MCCC Muhammadiyah regional leaders in the city of Surabaya and MCCC regional leaders of Muhammadiyah Malang. These areas are the areas most affected by covid-19 in East Java and Indonesia

In accordance with the characteristics of PAR research which is a branch of social research by emphasizing the description of phenomena and subjective data, the data that has been collected tries to be presented comprehensively. For this reason, the data collected from the questionnaire and interview instruments and deepened with literature study. Data analysis was qualitative through three stages: data reduction, data display, and conclusion drawing/verification, as a involve of socio-legal research for this paper (Wiratraman \& Putro, 2019).

\section{RESULTS AND DISCUSSION \\ Theory of Corruption}

Indonesia already has Law Number 30 of 2002 concerning the Corruption Eradication Commission (Law No.30/2002) (Al-Fatih, 2018). It has been amended in Law Number 19 of 2019 (Law No.19/2019) as a formal legal basis regarding the authority of the KPK. Meanwhile, related to the criminal act of corruption as a material legal basis, we can refer to Law Number 31 of 1999 concerning the Eradication of Corruption (Law No.31/1999) amended in Law Number 20 of 2001 (Law No. 20/2001), as well as related laws in Indonesia. In the Anti-Corruption Act, several 
types of corruption offenses are recognized, namely: (1). Bribery; (2). Embezzlement; (3). Extortion; (4). Conspiracy on criminal acts of corruption; (4). Corruption in the procurement of goods and services; (5). Gratuities; and (5). Corruption that harms state finances (Prakasa, 2020b).

Furthermore, as a state party to the anti-corruption international convention (United Nations Convention Against Corruption/UNCAC), Indonesia has ratified UNCAC into Law Number 7 of 2006 (Law No, 7/2006). The impact of this ratification is Indonesia obliged to apply and be bound as legal provisions in Indonesia. Ratification is needed in order to become a national legal regulation for the mechanism for handling corruption cases in Indonesia (Dumoli Agusman, 2017). At UNCAC, we can see various types of new corruption crimes that have not been regulated in the previous Corruption Act, such as: Bribery of foreign affairs, trading of influence, corruption in the private sector (bribery in private sector), to enrich themselves against the law (illicit enrichment), and so on (Prakasa, 2019b).

The occurrence of corruption is due to the lack of social control from the community. Based on the formula, as stated by Klitgaard: C > M + D - A [Corruption occurs when monopoly plus discretion without accountability]. Therefore, it needs to be equipped with social control (SC) so that it becomes: C> M + D - A - SC. This formula indicates that social control is absolutely necessary to create an absolute state system to be free from corruption (Klitgaard, 1998).

Corruption without social control will cause a weak law enforcement and tend to be permissive towards transactional practices in eradicating corruption (Cahyani \& AlFatih, 2020). Government legitimacy to prevent corruption eradication is also in a weak position, because they enjoy the process of running a corrupt general election and causing legislative products -The resulting legislation and policies issued also tend to compromise efforts to weaken corruption eradication and corruption has an impact on reducing the income of a country (Moene, 2016). Thus, the principles of accountability and social control are absolute choices so that the state order is not damaged by corrupt practices..

\section{Study of Legislation and State Policies in the Response of Covid-19}

At least there are several studies of legal regulations which will be presented in the following data to show the rights and obligations of the state on the one hand in the context of overcoming the Covid-19. And how the level of vulnerability that occurs in relation to potential misuse of the budget that can be categorized as social assistance corruption. How to mitigate it so that the potential for corruption is not affected, namely: 
Government and DPR-RI decided to increase the expenditure allocation in the APBN to Rp. 405.1 trillion. With an allocation for the health sector of Rp. 75 trillion, social protection Rp. 110 trillion, tax incentives and SME credit stimulus amounting to Rp. 70.1 trillion, and economic recovery credit of Rp. 150 trillion (Kementerian Keuangan RI, 2020). A large budget allocation for handling Covid-19 must be accompanied by transparency and accountability in its use. This includes the Government is expected to continue to involve the community in every decision making.

Through the allocation of funds amounting to Rp. 405.1 trillion from the APBN, the state allocated it for various sectors affected by the occurrence of Covid-19. The Indonesian government through the Ministry of Social Affairs and the Ministry of Villages has launched a series of social safety net programs such as Social Assistance $($ Bansos $=$ Social Assistance) $)$ and Direct Cash Assistance $(B L T=$ Direct Cash Assistance), Village Fund (DD = Village Fund), PKH (Family Hope Program)), and each other's (Hariri, 2020). Its implementation in the field shows that there are still many obstacles in its implementation/distribution, especially related to inaccurate data, which then results in undue beneficiaries This shows a considerable potential for perpetrators to commit corrupt behavior and corrupt practices (TII \& ICW, 2020).

The legal regulations that have been described above can be a method of analysis to what extent the effectiveness of their implementation in the field. The synergy between civil society through the method participatory action research is important. The goal is to observe so that the implementation of social assistance can be carried out on target, and in order to the misuse of social assistance is not misused and lead to corrupt practices. Muhammadiyah as one of the largest religious and community organizations in Indonesia, has all the tools and infrastructure through the MCCC as the lead sector in the context of tackling Covid-19 both in the aspects of health, education, economy and social welfare of the community, is a very strategic party in the context of mitigation risk of corruption misuse of social assistance Covid-19.

\section{The Role of Community in Corruption Mitigation}

Space for anti-corruption civil society is at the forefront of the agenda for the prevention and eradication of corruption crimes, this has been stated in Article 41 of Law Number 31 Year 1999 concerning Eradication of Corruption Crimes which states that:

1. Society can play a role as well as assisting efforts to prevent and eradicate corruption crimes.

2. Community participation as referred to in paragraph (1) is manifested in the form of:

a. The right to seek, obtain, and provide information on the suspicion of a criminal act of corruption; 
b. the right to obtain services in seeking, obtaining and providing information on suspicion of a criminal act of corruption to law enforcers handling corruption cases;

c. The right to convey suggestions and opinions responsibly to law enforcers who handle corruption cases;

d. The right to obtain answers to questions about the report given to law enforcers within a maximum period of 30 (thirty) days;

e. The right to obtain legal protection in terms of:

1) Exercising the rights referred to in letters $a, b$, and $c$;

2) Requested to be present in the process of investigation, investigation, and in court sessions as a reporting witness, witness, or expert witness, in accordance with the provisions of the prevailing laws and regulations;

3) The community as meant in paragraph (1) has the right and responsibility in the efforts to prevent and eradicate the criminal act of corruption.

4) The rights and responsibilities as referred to in paragraph (2) and paragraph (3) shall be exercised by adhering to the principles or provisions stipulated in the prevailing laws and regulations and by obeying religious norms and other social norms.

5) Provisions regarding procedures for implementing public participation in the prevention and eradication of criminal acts of corruption as referred to in this Article, shall be further regulated by a Government Regulation

Moreover, currently the KPK-RI portal is known as KPK Whistle Blower's System platform (KWS), which provides online access for anti-corruption civil society to report corrupt practices around it and is anonymous. This ensures the security and confidentiality of civil society data. However, it is possible to know the identity of the reporter because a network of thugs and mafias that are organized and able to be mobilized by corruptors and their cronies can easily repress civilians who are witnesses and/or have legal facts to reveal the various corrupt modus operandi perpetrated by officials. public, employers, and law enforcement officials (Prakasa, 2019a).

In this condition, the position of civil society is very vulnerable. Whereas the participation of civil society, either directly or indirectly, is through a series of empowerment works. civil society participation, and guarding various kinds of corrupt practices by both public officials and businessmen, guarding the running of policies with anti-corruption values. So that the participation of anti-corruption civil society is very influential in efforts to prevent and eradicate corruption and guard the course of development in a transparent and accountable manner (Hough, 2015).

In fact, the protection of civil society as whistleblowers in mitigating the practice of corruption has received guarantees of protection and security. Based on Article 5 of Law Number 13 Year 2006 concerning Protection of Witnesses and Victims, in the form of physical, psychological, information and data confidentiality protection to a new residence (Butt, 2014). 
The threats and backlash of corruptors with their network of thugs and mafias have really left the anti-corruption civil society in a vulnerable position. The presence of LPSK and its collaboration with the KPK are expected to be able to protect public participation in guarding against corruptive practices, while still protecting the freedom and security of conveying information and data on corrupt practices, both public officials, businessmen, and law enforcement officials around us (Basu, 2018).

\section{Muhammadiyah \& The Social Assistance Corruption Mitigation Movement.}

The presence of Muhammadiyah as a community organization and the oldest Islamic organization in Indonesia makes various Islamic da'wah more contextual. Especially in the case of anti-corruption jihad that was carried out. Given that the anticorruption jihad echoed by Muhammadiyah aims to uphold the existence of the da'wah of the organization on the one hand and avoid and punish corruption perpetrators who cause misery and violate the basic rights of the ummah on the other (Ulum, 2013).

An extraordinary impact when the anti-corruption Jihad carried out by Muhammadiyah is conveyed through anti-corruption religious discourse if it can be socialized to the general public and especially Muhammadiyah citizens through religious forums and equip all components of the Muhammadiyah organization, including preachers or preachers about lecture or sermon material. With anticorruption jihad theme, so that awareness and practice of the values of responsibility, trust worthiness, honesty and openness in all aspects can actually be carried out in everyday life(Tarjih \& Tajdid, 2006).

MCCC is an institution created by the Muhammadiyah Central Leadership for the task force for handling Covid-19 which has tasks in the fields of health, education, and social welfare which are not only for organizational citizens, but society at large. On March 19, 2020 PP Muhammadiyah issued a fatwa edict with the basis of the MCCC from a legal side through the Muhammadiyah Central Executive Declaration Number: 02/MLM/I.0/H/2020 Concerning Corona Virus Disease 2019 (Covid-19) Plages, Central Executive Muhammadiyah has formed the Muhammadiyah Covid-19 Command Center (MCCC) which is tasked with coordinating the implementation of the Covid-19 handling program and actions on March 12, 2020. Then, on March 14 Muhammadiyah formed the MCCC and then continued to East Java and MCCC in each district/City. 


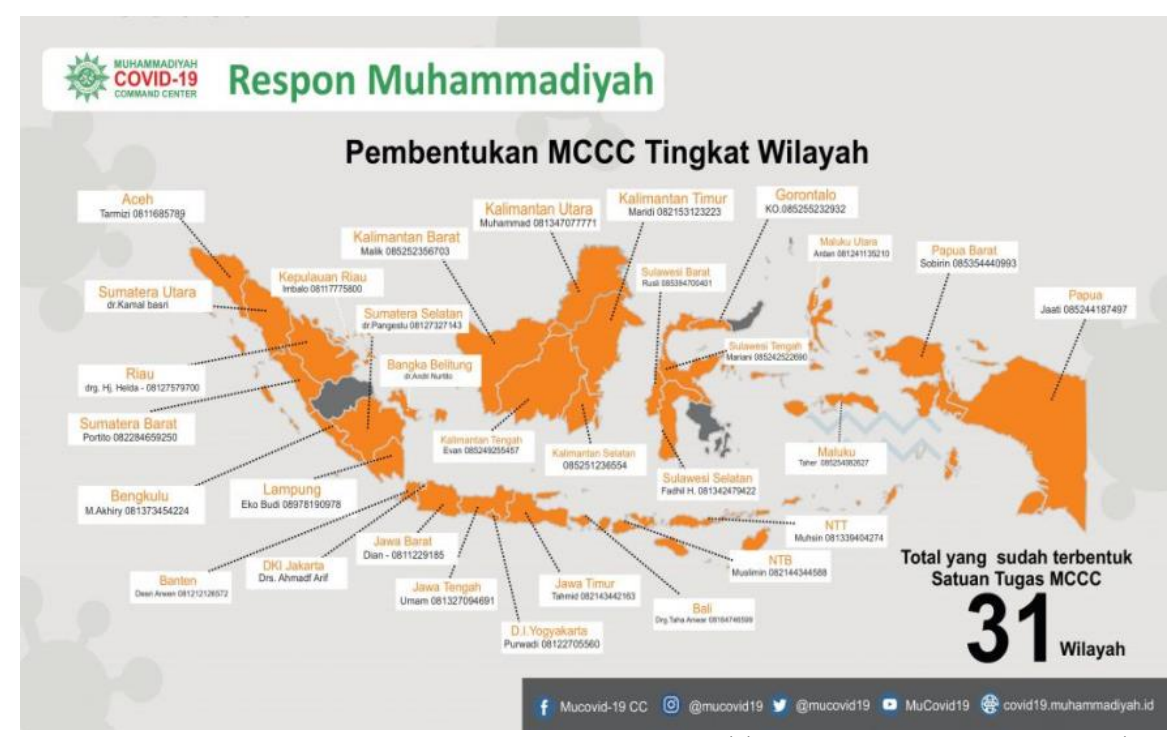

Figure 1. Muhammadiyah Responses, Source: https://covid19.muhammadiyah.id/tentangkami/, Access $20^{\text {th }}$ October 2020

In the implementation of the work carried out, MCCC does not go alone, MCCC consists of the following elements: the Public Health Advisory Council (MPKU); Muhammadiyah Disaster Management Center (MDMC); 'Aisyiyah; LAZISMU; Council of Higher Education and Research Development (DIKTI LITBANG); Elementary and Secondary Education Council (DIKDASMEN); Tabligh Council; Muhammadiyah Student Association (IPM); Muhammadiyah Student Association (IMM); Nasyiatul 'Aisyiyah (NA); Hizbul Wathan (HW); Tapak Suci Putera Muhammadiyah (TSPM), as well as; Muhammadiyah Youth. This synergy from the central, regional, regional, branch to branch levels confirms that the MCCC's position is very ready and authoritative in tackling the spread of Covid-19 to the grassroots (MCCC, 2020b).

\section{East Java: Duties and Responsibilities of the Right Target Distribution of Social Assistance}

The East Java MCCC was formed based on the Decree of the East Java Muhammadiyah Regional Leadership Number: 1777/KEP/II.0/D/2020, regarding the Establishment of the Muhammadiyah Covid-19 Command Center of East Java. In order to support the activities carried out by the East Java MCCC in the context of tackling Covid-19, form a representation of the MCCC in 38 Regencies/Cities of Muhammadiyah Regional Leaders in East Java. The aim is to coordinate and take tactical steps to minimize the spread of Covid-19 in each Regency/City under the authority of the Muhammadiyah Regional Leaders (Pimpinan Daerah MuhammadiyahPDM). 
In addition, the establishment of the MCCC at each PDM is to become a post and collect assistance, both from the Government, the private sector, and solidarity between citizens, as well as a call center for distribution to social assistance monitoring on Covid-19. Regional Command Post in East Java under the coordination of MCCC PWM East Java, PWM Muhammadiyah East Java Building, Jl. Kertomen date IV/1 Surabaya, while the Regional Command Post, Lazismu office (PDM) of each Regency/City in East Java.

At least there are several work areas that are under the authority of the East Java MCCC which is a derivative of the authority of the Central MCCC and then translated by the District/City MCCC as the vanguard in the response to Covid-19. Based on the line of instructions from the East Java Muhammadiyah Regional Leadership, MCCC East Java has all the tools and infrastructure that are always ready in case of problems as a result of the spread of the pandemic. The scope of work of the East Java MCCC consists of three areas, namely: health, education, and economy \& social welfare.

"Related to if there is a disaster or pandemic like this. East Java itself already has 5 operational vehicles, including assistance channeled from Lazismuh which comes from both the Government (Governor, Kapolda Jatim, and Pangdam V Brawijaya), assistance from private entrepreneurs/entities, as well as voluntary donations collected to be converted into aid. in the form of: PPE and ventilator for the Muhammadiyah Hospital network throughout East Java, canned fast food (your rendang, sotomu, etc.)" (Masyhudi, 2020).

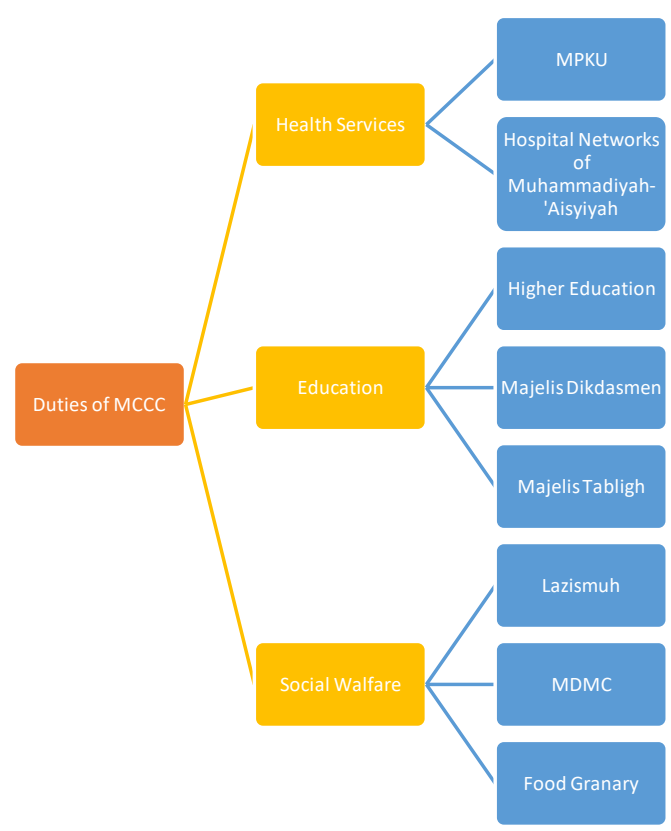

figure 2. Field area of MCCC East Java 
Including, in the education aspect, where the PP has determined that Muhammadiyah will take a teaching and learning position online. So that the scope and work of the MCCC can be said from upstream to downstream, starting from preventive and curative steps in the medical aspect by involving the RSM network throughout East Java Province to downstream aspects related to the needs and welfare of the community, including in the aspect of education.

The distribution of donations is used for the preventive and curative agenda, as well as the economic \& food security agenda. The preventive and curative agenda is allocated for: (1). Spray disinfectant: 20,595 dots; (2). Distribution of disinfectants: 2,407 liters, 40 tanks; (3). Distribution of hand sanitizer: 304 liters, 3,584 bottles; (4). Distribution of hand soap: 450 liters, 1338 packages; (5). Distribution of masks: 28,557 pcs; (6). Billboards, education and publications: 13 units; (7). Digital education platform: 8 Regional IG accounts; (8). Educational posters: 5,060 sheets; (9) Economic \& Food Security. Meanwhile, the distribution of economy and social welfare is in the form of: (1). Food packages: 108,040 packages; (2). Cash assistance of Rp. 14,000,000,(MCCC \& Lazismuh, 2020).

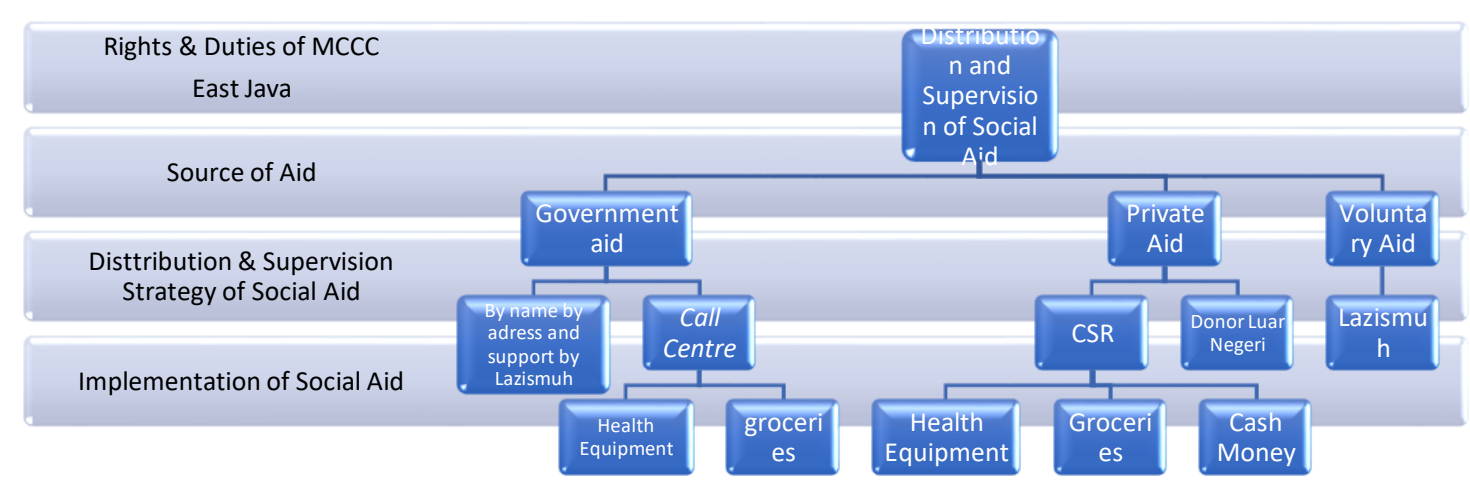

Figure 2. East Java Social Aid COVID-19 MCCC distribution and monitoring framework

The process of distributing social assistance carried out by MCCC East Java is based on the correct input and database from Branch and Sub-Branch Managers as well as Lazismuh assistance in order to make the assistance right on target by name by address. The distribution of this assistance was carried out both from the Government and from the private sector as well as from non-governmental organizations and Muhammadiyah sympathizers. Hamid said "The presence of call centers at each regional post is proof that what MCCC East Java is doing is being carried out on target. The East Java MCCC work process will continue until the Covid-19 problem is 
declared complete and a vaccine is found for the prevention and cure of Covid-19” (Hamid, 2020).

The importance of participation and collaboration of all stakeholders carried out by the East Java MCCC is key in the context of overcoming Covid-19 in East Java. Through participatory work and carried out in a transparent and accountable manner, and this is owned by MCCC East Java with all organizational features and a very wide range of power.

Then, as one of the largest Regency/City level MCCC in East Java, with the prevalence level of the spread of Covid-19, the City of Surabaya and the City of Greater Malang are the most affected areas. it is reasonable if it is necessary to look at the good practices carried out by MCCC in the City of Surabaya and MCCC Malang Raya in overcoming Covid-19 on the one hand, and management strategies to supervision of social assistance so that there is no abuse and corrupt practices carried out by parties. who are not responsible.

\section{Surabaya and Branch Solidarity Guarding COVID-19}

MCCC Surabaya was formed based on the PDM Surabaya City Decree Number: 507/KEP/III.0/D/2020. On its journey, MCCC Surabaya City received assistance from the Mayor of Surabaya in the form of empon-empon (herbal drink to increase immunity), hand sanitizer, disinfectant, sprayer, 1 ton of rice, and basic food packages managed by the food barn. Meanwhile, the Governor of East Java received and distributed basic foodstuffs to affected residents in the city of Surabaya. MCCC Surabaya does not receive assistance in the form of funds from the government because it is feared that it will pose a risk to legal problems that occur, even though the legal mechanism has regulated and protected this. Therefore, MCCC Surabaya only receives assistance in the form of goods. The majority of assistance comes from individual assistance and the most times are before holidays, zakat mal and zakat fitrah are submitted to the MCCC due to the lockdown of mosques. (Arifan, 2020).

In executing aid, MCCC helps oversee government assistance programs that are distributed to the community through the Surabaya City Social Service. Through proposals for related people who are directly affected not only from the MCCC in the form of finance, so that the community can accept directly or be right on target. In overseeing this program MCCC matched the NIK (resident code) of the community registered with the BLT or affected people. So assistance is not only from the MCCC, but encourages helping the affected people. MCCC also helps with the admission of new students in schools, by providing access for MCCC volunteers to make their schools prosperous. Thanks to the assistance of the Governor of East Java and the East Java Provincial Secretary, to provide children from families affected by COVID19 to continue their education for free and receive scholarships. So MCCC Surabaya does not only pay attention to economic aspects, but also pay attention to education and health (Arifan, 2020). 
MCCC Surabaya City also opened a post for complaints about the distribution of social assistance, and received many reports from the public. The contents are complaints related to the distribution of social assistance which is considered uneven. There are also those who are considered not on target. In fact, every RT/RW already has data on low-income people (MBR). In addition, each RT/RW has been asked to record data on non-MBR residents affected by the pandemic. The cause of the wrong targeting assistance lies in the verification and validation of the data. Starting at the RT/RW level, sub-district, until the Surabaya City Social Service (Dinsos).

The verification process is not only done on paper. Officers should look directly at the conditions of prospective social assistance recipients in the field. Because, it is not certain that the economic conditions of people who have nice houses are fine. In a situation like this, many people who were previously able suddenly fall into poverty. The cause is layoffs (termination of employment) or being laid off, including people who suddenly have low income (Frizal, 2020). This is the importance of participatory steps driven by Muhammadiyah through the MCCC, as well as the active involvement of citizens so that then they understand and then mitigate and advocate for various forms of practice that lead to the abuse of Bansos Covid-19.

\section{Malang Raya and AUM Synergy Guarding Transparent \& Accountable Social Assistance for Covid-19}

MCCC Malang Raya is also no less inspirational in the framework of guarding the social assistance provided by the Government, both at the central level to the regencies/cities, especially those in the Greater Malang area (Malang City, Malang Regency, and Batu City). MCCC Malang Raya distributes various forms of social assistance, ranging from logistical assistance from BNPB in the form of basic food packages consisting of rice, canned food, etc. which have been distributed by the MCCC Malang Raya team in collaboration with Maharesigana, a team of volunteers who assist MCCC Malang Raya in social action, who also worked with Lazismuh and MDMC so that aid distribution could be carried out on target (Osmon, 2020).

Included in the medical field which is the main focus of the work of MCCC Malang Raya, where there is one of the Muhammadiyah Business Charities (AUM) in the health sector, namely the University of Muhammadiyah Malang Teaching Hospital (RS UMM) which was appointed as one of the referral hospitals for treatment. Covid19 patients in Malang Raya. UMM Hospital with various situations and conditions has been deemed successful in surviving amid the increasingly rampant Covid-19 pandemic. MCCC Malang Raya realizes that in the journey of health services for Covid19 patients, there are pros and cons, considering that at the peak of the pandemic, there was a crowd of health services carried out by UMM Hospital, but dharma-bakti Muhammadiyah in overcoming the pandemic as was done by UMM Hospital 
continued. running, where the level of risk of transmission, the process of circulation of patients and health workers in the hospital, to hospital management are really tested (Djauhari, 2020).

MCCC Malang Raya said, there are various assistance provided by the Government, especially in terms of medical devices (medical equipment) that are directly provided. Medical devices such as: ventilators, masks, PCR, and others were given directly without coordination from the hospital, so it was found that medical equipment was not in accordance with the needs and even required additional equipment that had to be issued by the hospital, of course this was inefficiency and in the end, MCCC Malang Raya chose which medical equipment and PPE were good in the context of mandis for Covid-19 patients, which were then intended for non-medical purposes, such as catering, administration, and reviewing (Djauhari, 2020).

The government has tried to develop medical equipment such as PCR, but is it running well, or does it need additional devices such as a compatible extractor so that the tool can be effectively used in the response to Covid-19, additional costs for additional equipment so that PCR is donated from the Malang Regency Government, can do tracing as many as 1,000 inspectors assistance from Malang Regency Government, although it is quite helpful but it is not yet effective. Furthermore, if we look at the assistance from the government, for example in the form of money, for a specialist doctor per/doctor it is Rp. 15,000,000. For general practitioners, IDR $10,000,000$. However, the implementation is not like that, but depends on the number of patients treated. Of course, the real condition in the field that understands the response to Covid-19 is the hospital itself. Therefore, the authority to provide important assistance then pays attention to the needs and desires of the hospital, considering that they set the front line in dealing with Covid-19, especially in Malang Raya (Djauhari, 2020).

In fact, based on data from Malang Corruption Watch (MCW), it was stated that the allocation of funds for the response to Covid-19, in Batu City. The first allocation per-20 March 2020 is IDR 7 billion taken from DAK Physical and Excise IDR 2.5 billion IDR and IDR 4.5 billion IDR from various sectors, and there is no explanation of which sector is meant. The second allocation per 3 April 2020 amounted to 29.4 billion and 6 and the latest as of 6 April 2020 amounted to Rp. 59.5 billion Rupiah. Malang City, the first allocation per March 22 was 2.5 billion which was taken from unexpected funds of Rp. 2,150 billion Rupiah, and Rp. 400 million from Special DID. The second allocation per March 28 was Rp. 37.3 billion, one of which was taken from official travel. Then it is allocated again as of March 30, amounting to Rp. 58.2 billion. Likewise, Malang Regency, namely as of March 26, amounting to IDR 15 billion, and as of March 28, IDR 28 billion (Watch, 2020).

Malang Regency Government has allocated a budget of around IDR 28 billion to tackle Covid-19. The budget is small when compared to the work that must be 
completed. When compared to other areas of Malang Raya, the funds allocated by the City of Malang are much larger, namely Rp. 37 billion Rupiah. Even though the population and area of Malang Regency is much larger than Malang City (Watch, 2020). If the fund allocation is used in a transparent and accountable manner, the community will feel the impact, both for preventive, promotional and curative purposes. This is where it is important to be conscious and participatory in escorting Covid-19 Social Assistance to be right on target, as was done by MCCC Malang Raya.

MCCC Malang Raya also encourages the participation of Muhammadiyah Branch Leaders throughout Malang Raya in the context of prevention and promotion through awareness of health protocols and $3 \mathrm{M}$, including moving the cleanliness of the village environment, mosques, schools, etc. This indirectly reduces the burden of curative and medical costs which tend to be large and the risk of transmission to a high mortality rate. So, the steps taken by MCCC Malang City will be able to create a Regency / City that is resilient in facing COVID-19, both that has an impact on the health aspect, as well as other factors that follow such as economy, social welfare, and so on.

\section{CONCLUSION}

1. Corruption of the Covid-19 Social Assistance Agency is a serious threat and is detrimental to the Indonesian people who were severely affected by the pandemic, even though the Corruption Act has provided a serious threat to perpetrators of corruption committed during a disaster, with a maximum penalty of death. However, based on Law Number 2 of 2020 Provides immunity for the government not to be prosecuted legally in the use and distribution of budget from the State Budget in the context of overcoming Covid-19. Conflict of norms in legislation regarding the eradication of corruption in Social Assistance Covid-19 needs to be clarified in order to ensure that effective penalties for perpetrators of corruption during the Covid-19 period can be dealt with through maximum punishment.

2. The KPK-RI as the lead sector for corruption eradication in Indonesia can collaborate with various community groups on the agenda of eradicating corruption in Indonesia, especially the corruption of Covid-19 social Aid, through access to community-based reporting, it is hoped that the affected community groups can become watchdogs to ensure Covid-19 assistance in accordance with the realization of the budget, specifications, as well as right on target both in the allocation for basic food, cash and other assistance such as medical devices, as well as other types of social assistance.

3. As one of the Islamic social organizations in Indonesia, Muhammadiyah has various instruments and strategic roles to guard against misuse of social assistance. Through the MCCC, Muhammadiyah can contribute in providing medical to non-medical assistance as well as channeling aid from both government and non-government donors in an appropriate manner. Thus, Participatory Action Research carried out by Muhammadiyah East Java residents is an effective step and a good example of 
how social entities can mitigate the potential for social assistance corruption of Covid-19 which is carried out both with a structural to cultural approach.

\section{ACKNOWLEDGEMENT}

Thanks to the PP Muhammadiyah Diktilitbang Council and PP Muhammadiyah Lazismuh for COVID-19 Research, to all the Leaders of the University of Muhammadiyah Surabaya c.q LPPM UMSurabaya for their support for the completion of this research and for the Editor and Reviewers of Legality: Jurnal Ilmiah Hukum.

\section{REFERENCES}

Al-Fatih, S. (2018). DARUS AS AN ANTI-CORRUPTION EDUCATION. Asia Pacific Frand Journal, 3(1), 117-123. https://doi.org/10.21532/apfj.001.18.03.01.14

Arifan. (2020). Strategi Cabang Ranting dalam Penanggulangan COVID-19 di Kota Surabaya.

Basu, K. (2018). Institution Governance and The Controll of Corruption. Palgrave MacMillan.

Butt, S. (2014). Assessing judicial performance in Indonesia: the court Corruption Crimes. Crime Law Soc Change, 62(1), 603-619.

Cahyani, T. D., \& Al-Fatih, S. (2020). Peran Muhammadiyah dalam pencegahan dan pemberantasan tindak pidana korupsi di kota batu. Justitia Jurnal Hukum, 4(2), 117-123. https://doi.org/10.21532/apfj.001.18.03.01.14.Volume

Djauhari, T. (2020). Strategi AUM dan MCCC Malang Raya dalam Penanggulangan COVID-19.

Dumoli Agusman, D. (2017). International Treaty Law of Indonesian Theory and Practice Studies. Refika Aditama.

Frizal. (2020). Butuh Verifikasi Lapangan Data Penerima Bansos di Surabaya. Jawa Pos.

Haliim, W. (2020). Problematika Kebijakan Dana Hibah dan Bantuan Sosial Sumber APBD: Relasi Korupsi Terhadap Kekuasaan Kepemimpinan, dan Perilaku Elit. JURNAL INOV ASI, 17(1), 39-53.

Hamid, N. (2020). Strategi PWM dan Lazismuh Jatim Dalam Penanggulangan COVID-19.

Hariri, A. (2020). The Politics of Law Concerning The Tenure of Village Head Reviewed From The Constitualism Perspective. PETIT A: Jumal Kajian Ilmu Hukum Dan Syariah, 5(1), 33-42.

Haris, \& Al-Fatih, S. (2020). School of Intuition as An Education for Child to Prevent Corruption in Indonesia. TEST Engineering \& Management, 83, 1188411892.

Hastuti, R. K. (2020). Sempat Zona Hitam, Pasien Covid-19 di Jatim Tambah 365 Orang. 
CNBC Indonesia.

Hough, S. V. (2015). People power and anti-corruption; demystifying citizen-centred approaches. Crime Law Soc Change, Published by Springer Science+Business Media Dordrecht, 64(23-35), 20-21.

Indonesia, C. (2020). Kronologi Mensos Juliari Jadi Tersangka Kasus Bansos Corona. CNN Indonesia.

Kementerian Keuangan RI. (2020). APBN Kita: Peluang dan Evaluasi. Kementerian Keuangan RI.

Kemmis, S., McTaggart, R., \& Nixon, R. (2014). The Action Research Planner: Doing Critical Participatory Action Research. Springer Science+Business Media.

Klitgaard, R. (1998). Controlling Corruption. University California Press.

LBH Jakarta. (2013). PARTICIPATORY ACTION RESEARCH (PAR). LBH Jakarta.

Masyhudi, T. (2020). Strategi dan Kerja MCCC Dalam Penanggulangan COVID-19 di Jawa Timur.

MCCC. (2020a). Tentang Kami MCCC. Muhammadiyah Covid-19 Command Center.

MCCC. (2020b). Tim Kami MCCC. Muhammadiyah Covid-19 Command Center.

MCCC, \& Lazismuh. (2020). Info Data Tanggap Covid-19: Penghimpunan dan distribusi Bansos oleh Persyarikatan Mubammadiyah di Jawa Timur. Lazismuh.

Moene, K. (2016). Corruption Control. Crime Law Soc Change, 66, 147-163. https://doi.org/10.1007/s10611-016-9618-6

Ombudsman RI. (2020). Potensi Maladministrasi dan Korupsi Bansos Covid-19. Ombudsman RI.

Osmon, D. (2020). MCCC Kota Malang Gerojok Rp 1 Miliar-8 Ribu Paket Sembako Bantu Umat Atasi Pandemi. Tabloid Matahati.

Prakasa, S. U. (2019a). Anti-Corruption Survivor, Academic Freedom, and the Challenges. PETITA: Jurnal Kajian Ilmu Hukum Dan Syariah, 4(2), 162-173.

Prakasa, S. U. (2019b). Garuda Indonesia-Rolls Royce Corruption, Transnational Crime, and Eradication Measures. Lentera Hukum, 3(3), 407-424.

Prakasa, S. U. (2020a). Covid-19 vs Anti-Korupsi di Indonesia. IB Times.

Prakasa, S. U. (2020b). Social Control Movement as a Corruption Eradication Instrument in Indonesia. Wacana Hukum, 26(1), 21-30.

Prasetyo, A. (2020). Empat Potensi Korupsi Pemberian Bansos Covid-19. Hukum Online.

Tarjih, M., \& Tajdid, P. M. (2006). Fikih antikorupsi : perspektif ulama Mubammadiyah / Majelis Tarjih dan Tajdid, PP. Mubammadiyah. Pusat Studi Agama dan Peradaban. 
TII, \& ICW. (2020). Buku Panduan Pengawasan Panduan Pemantauan Jaring Pengaman Sosial (Bansos) dalam Penanganan Covid-19 ba gi Masyarakat Sipil. TII.

Transparency International. (2018). Indonesia Overview of Corruption and Anti-Corruption. Transparency International.

Transparency International. (2019). Corruption Perseption Index 2019. Transparency International.

Ulum, B. (2013). Menggagas Konsep Fikih Anti Korupsi: Solusi Alternatif Pemberantasan Korupsi di Indonesia. Al-Manabij: Jurnal Kajian Hukum Islam, 7(1), 77-88. https://doi.org/doi.org/https://doi.org/10.24090/mnh.v7i1.578

Watch, M. C. (2020). Catatan Kritis tentang kebijakan Penanganan COVID-19 di Malang Raya. MCW Press.

Wiratraman, H. P., \& Putro, W. D. (2019). Tantangan Metode Penelitian Interdisipliner Dalam Pendidikan Hukum Indonesia. Jurnal Mimbar Hukum, 31(3), 403-415.

Zuber-Skerritt, O. (2016). The action research planner: doing critical participatory action research. Journal: Educational Action Research, 24(1), 150. 